dog in an effort to detect any circulating toxin. The transfused dog showed no evidence of paralysis. Fergus J. O'Rourke

Veterinary and Medical Entomology Unit, Entomology Division, Science Service,

Canada Department of Agriculture, Ottawa.

Maurice F. Murnaghan

Department of Pharmacology,

University of Ottawa. Aug. 20.

${ }^{3}$ Gregson, J. D., Proc. Ent. Soc. British Columbia, 40, 19 (1943).

2 Ross, I. C., Aust. Coun. Sci. and Ind. Res., 8, 8 (1935). Oxer, D. T., ass, I. C., Aust. Coun. Sci. and Ind. Res., 8, 8 (1935).

${ }^{3}$ Hindmarsh, W. L., and Pursell, R. T., Aust. Vet. J., 11, 229 (1935).

\section{Insecticidal Synergism with Valone}

THE insecticidal properties of valone (2-isovaleryl 1,3-indandione) were being investigated some years ago ${ }^{1}$, when the material was apparently eclipsed by the discovery of DDT. Recent tests on insect pests of stored products have shown that, although not outstandingly insecticidal by modern standards, valone has an unusual combination of properties; namely, (1) if the dose is high enough to be lethal, it kills the insects rapidly, (2) in sub-lethal doses it produces a paralysis from which insects afterwards recover, and (3) the percentage mortality is unusually sensitive to changes in dose. (2) indicated that insects can detoxify valone. By analogy with the probable mode of action of synergists for pyrethrins ${ }^{2}$ and $\mathrm{DDT}^{2}$, that is, depression of the normal detoxification of the insecticide, it seemed possible that the insecticidal action of valone could be intensified by suitable synergist. Furthermore, (3) suggested that the synergist need not be highly efficient in order to increase the mortality considerably.

A number of compounds were therefore tested in the laboratory for synergism with valone, using the flour beetle, Tribolium castaneum Herbst, as the test species. Most, including pyrethrin synergists, did not synergize valone appreciably, but certain insecticides did so, especially pyrethrins and gamma-BHC (gamma-hexachlorocyclohexane). Table l gives results obtained with these insecticides applied as direct sprays ${ }^{4}$ in refined kerosene. That synergism occurred is supported by the fact that the mixtures combined an enhanced toxicity with the rapid lethal action of valone. Kerr ${ }^{5}$ gave data suggesting that synergism occurs between valone and pyrethrins applied to houseflies.

The larvæ of the Khapra beetle, Trogoderma granarium Everts, are exceedingly resistant to the contact insecticides in general use ${ }^{6}$, and even lethal

Table 1. TOXICITY* TO FLOER BEETLES, Tribolium castaneum, of Table 1. TOXICITY TO FLOUR BEETLES, Tribolivm castaneum, of
MIXTURES CONTAINING VALONE, AND OF THE SEPARATE CONSTITUENTS

\begin{tabular}{|c|c|c|c|}
\hline \multirow{3}{*}{$\begin{array}{l}\text { Spray } \\
\text { (concentrations, per cent } \mathrm{w} / \mathrm{v} \text { ) } \\
2 \cdot 0 \text { per cent valone } \\
0 \cdot 3 \text { per cent pyrethrins } \\
2 \cdot 0 \text { per cent valone }+0.3 \text { per } \\
\text { cent pyrethrins }\end{array}$} & \multicolumn{3}{|c|}{$\underset{2 \cdot 5}{\operatorname{Spray}}$ deposit (mgm. 10 sq. cm.) } \\
\hline & $\begin{array}{l}0 \\
0\end{array}$ & $\begin{array}{l}0 \\
2\end{array}$ & $\begin{array}{l}32 \\
10\end{array}$ \\
\hline & 10 & 20 & 92 \\
\hline \multirow{2}{*}{$\begin{array}{l}2 \cdot 0 \text { per cent valone } \\
0 \cdot 4 \text { per cent gamma-BHC } \\
2 \cdot 0 \text { per cent valone }+0.4 \text { per } \\
\text { cent gamma-BHC }\end{array}$} & $\begin{array}{l}0 \\
0\end{array}$ & $\begin{array}{l}0 \\
4\end{array}$ & $\begin{array}{l}30 \\
20\end{array}$ \\
\hline & 12 & 58 & 88 \\
\hline
\end{tabular}
*As shown by mortalities (per cent) in batches of 50 beetles kept
at $25^{\circ} \mathrm{C}$. for three days after spraying. doses of these are very slow to kill. Mixtures containing valone with pyrethrins or gamma-BHC were therefore applied to larvæ, to discover whether the rapid action of valone might be useful in their control. As sprays in refined keroserie, the lethal action on the larvæ was rapid, but the synergism only moderate. However, as a dust on talc, a mixture of valone with gamma-BHC showed both a rapid lethal effect and marked synergism. Table 2 illustrates this. Even if mixtures of valone with gamma-BHC or pyrethrins should prove inapplicable to the practical control of Trogoderma, the existence of $a$ formulation so toxic and swiftly lethal encourages the hope that a contact insecticide effective ag sinst these resistant larvæ can be found.

Table 2. ToxidTT* TO LARVA OF THE KHAPRA BRETLE. Trogoderma granarium, OF A MIXTURE CONTAINING VALONE AND GAMMA-BHC,

\begin{tabular}{|c|r|r|}
\hline AND OF THE SHPARATE CONSTITURATS \\
Dust & Temperature \\
(concentrations, per cent w/w) & $25^{\circ} \mathrm{C}$. & $30^{\circ} \mathrm{C}$ \\
\hline $5 \cdot 0$ per cent valone & 11 & 20 \\
0.5 per cent gamma-BHC & 0 & 0 \\
$5 \cdot 0$ per cent valone +0.5 per cent gamma-BHC & 77 & 100 \\
\hline * As shown by mortalities (per cent) in batches of 100 larvæ after
\end{tabular}

This communication is publish 3 d by permission of the Department of Scientific and Industrial Research.

Pest Infestation Laboratory, P. S. HEWLETT

Department of Scientific and Industrial Research, Slough. Sept. 26.

I Kilgore, L. B., et al., Indust. Eng. Chem. (Indust.), 34, 494 (1942). Eddy, G. W., and Carson, N. B., J. Econ. Ent., 39, 763 (1946). ${ }^{2}$ Winteringham, F. P. W., Proc. 3rd Int. Cong. Phytopharmacy, Paris; 1952 (in the press).

S Perry, A. S., and Hoskins, W. M.. Science, 111, 600 (1950).

4 Hewlett, P. S., Ann. App. Biol, 34, 357 (1947).

${ }^{6}$ Kerr, R. W., Bull. Commonwealth Sci. Indust. Res. Org., Aust., No. 261 (195i).

'Cotterell, G. S., and Howe, R. W., "Insect Infestation of Stored Products in Nigeria" (H.M.S.o., 1952). Parkin, E. A. (unpublished).

\section{Relation between the Quality of Soybean Oil Meal and the Requirements of Vitamin $B_{12}$ for Chicks}

VARYING results from some experiments with chicks, using pure vitamin $\mathrm{B}_{12}$ in all-vegetable diets, have led to the conclusion that the quality of the soybean oil meal used must be taken into consideration.

In two series of experiments, carried out in the early months of 1953 , the addition of pure vitamin $B_{12}$ to an all-vegetable diet gave ample and significant growth responses. In addition, the chicks in these experiments responded significantly to lowered calcium content in the diet, iron supplement or added vitamin $D$, although these factors were thought to be adequate in the diet.

In two further series, there was no growth response at all. The chicks fed the basal vitamin $B_{12}$-free diet grew at the same rate as the vitamin $B_{12}$-supplemented chicks. The other factors mentioned above also failed to give growth responses.

As a standard procedure in vitamin $B_{12}$-experiments on chicks at this animal experiment station, the method adopted by Rubin and Bird ${ }^{1}$ is used. Dayold chicks from non-depleted hens are fed an allvegetable diet for the first two weeks, and then 